\title{
Feeding mechanism of the polychaete Sabellaria alveolata revisited: comment on Dubois et al. (2005)
}

\author{
Hans Ulrik Riisgård ${ }^{1, *}$, Claus Nielsen ${ }^{2}$ \\ ${ }^{1}$ Marine Biological Research Centre, University of Southern Denmark, Hindsholmvej 11, 5300 Kerteminde, Denmark \\ ${ }^{2}$ Zoological Museum (The Natural History Museum of Denmark, University of Copenhagen), Universitetsparken 15, \\ 2100 Copenhagen, Denmark
}

\begin{abstract}
Recently, Dubois et al. (2005; Mar Ecol Prog Ser 301:159-171) described the feeding mechanisms of the sabellariid polychaete Sabellaria alveolata and concluded that it is a ciliary suspension feeder that uses alternately a downstream- and an upstream-collecting system. We reinvestigated both the ciliated epithelia (scanning electron microscopy and transmission electron microscopy) and the function (video microscopy) of the tentacle crown of $S$. alveolata. We found that the tentacles of intact and undisturbed $S$. alveolata have a large number of stiff ciliary spikes, each flanked by an actively beating cirrus, but no structured flow of water is created and only minor local currents can be seen. Clearly, S. alveolata has neither a ciliary downstream-collecting system nor a proper ciliary pump as found in upstream-collecting bryozoans, phoronids and brachiopods. Our findings indicate that $S$. alveolata's tentacle crown is designed for passive suspension feeding and thus dependent on ambient currents to bring suspended food particles into contact with the tentacles. The significance of the conspicuous ciliary spikes remains unknown, but our observations suggest that mucus is involved in both capture and transport of food particles.
\end{abstract}

KEY WORDS: Suspension feeding · Particle capture · Video-microscope observations $\cdot$ Ciliated tentacles $\cdot$ Ciliary spikes $\cdot$ Sabellaria alveolata $\cdot$ Fabricia stellaris

\section{INTRODUCTION}

In ciliary suspension-feeding serpulid and sabellid polychaetes a ciliated tentacle crown acts as a downstream-collecting system, based on the 'catch-up principle' (Riisgård et al. 2000, 2002). Here, compound lateral cilia generate a feeding current that enters the ciliary region where the same cilia, during their power stroke, catch up with suspended particles and transfer them to a frontal band of cilia on the downstream side. A completely different ciliary feeding mechanism has been described for bryozoans (Riisgård \& Manríquez 1997, Nielsen \& Riisgård 1998, Larsen \& Riisgård 2002), phoronids (Riisgård 2002), and brachiopods (Gilmour 1978, Nielsen 1987), where lateral ciliary bands work in an upstream-collecting system, partially employing a filter formed by stiff, sensory laterofrontal cilia. Recently, Dubois et al. (2005) described the feeding mechanisms of the sabellariid polychaete Sabellaria alveolata and concluded that it is a suspension feeder which uses a ciliary system resembling that of serpulid and sabellid polychaetes, but which should work alternately as a downstream- and an upstream-collecting system. Because we did not find the documentation of the ciliary feeding mechanism adequate, we decided to re-investigate both the ciliated epithelia and the function of the tentacle crown of $S$. alveolata. 


\section{MATERIALS AND METHODS}

Blocks of tubes of the sabellariid Sabellaria alveolata (Linnaeus, 1767), with additional specimens of the sabellid Fabricia stellaris (Müller, 1774) $(=$ F. sabella Ehrenberg, 1836) were obtained from the Station Biologique, Roscoff, Brittany, France, in January 2006, and kept in a saltwater tank (33 psu; $14^{\circ} \mathrm{C}$ ) at the Marine Biological Research Centre, Kerteminde, Denmark, where the video-microscope observations were conducted during the following weeks at the laboratory room temperature $\left(\right.$ ca. $\left.18^{\circ} \mathrm{C}\right)$. The mean $( \pm \mathrm{SD})$ body wet weight and dry weight $\left(90^{\circ} \mathrm{C}, 24 \mathrm{~h}\right)$ was $74 \pm$ 24 and $14 \pm 5 \mathrm{mg}(\mathrm{n}=10)$, respectively. Specimens for investigation of stomach contents were collected at low tide from the beach of St. Efflam, Brittany, and fixed in alcohol immediately. The stomach content was subsequently dissected out and inspected under a compound microscope.

Scanning electron microscopy (SEM). Material for SEM was narcotized with $\mathrm{MgCl}_{2}$, fixed gently with a small drop of $1 \%$ formalin in seawater and fixed in $1 \%$ $\mathrm{OsO}_{4}$ in distilled water. Dehydration was through an acetone series. The specimens were critical point dried, mounted on double-sided stick tape and coated with platinum-palladium. The paddle cilia shown in most of the scanning electron micrographs indicate that the specimens have encountered osmotic stress during fixation; in living animals, this is a reversible process which seems only to influence the tip of the cilia (Nielsen 1987).

Transmission electron microscopy (TEM). Material for TEM was narcotized with $\mathrm{MgCl}_{2}$, fixed in $2.5 \%$ glutaraldehyde in $0.1 \mathrm{M}$ cacodylate buffer, postfixed for $1 \mathrm{~h}$ in $1 \% \mathrm{OsO}_{4}$ in distilled water and embedded in araldite.

Video-microscope observations. Tentacular ciliary activity and particle processing were observed by means of both a horizontal stereo microscope with a built-in video camera (Leica MZ8) connected to a 50 half-frames $\mathrm{s}^{-1}$ video recorder (Panasonic NV-FS200 $\mathrm{HQ}$ ), and an inverted microscope (Leica DM IRB) equipped with a high-speed digital camera (CMOS camera MC13xx, recording 280 frames s${ }^{-1}$ ) connected to a computer. A colony of animals $(\mathrm{l} \times \mathrm{w} \times \mathrm{h}=\mathrm{ca} .12 \times$ $8 \times 5 \mathrm{~cm}$, with a population density of 2 to 3 ind. $\mathrm{cm}^{-2}$ surface) was placed in an observation aquarium in front of the stereo microscope; a peristaltic pump could be activated to ensure a re-circulating flow of water, with re-suspended natural seston particles from the collection site, past the tubes of worms with extended tentacle crowns. To study the tentacles at high magnification, worms within their natural tubes were placed in a small observation chamber $(1 \times \mathrm{w} \times \mathrm{h}=7 \times 3 \times$ $1.2 \mathrm{~cm})$ placed on the inverted microscope. About
$15 \mu \mathrm{m}$ diameter algal cells (Tetraselmis sp.) and seston from the collection site were added to the water in the observation chamber. Ciliary activity and particle movements were traced from their positions in successive video frames.

\section{RESULTS}

\section{Structure of the tentacles}

The lateral faces of the tentacles have a complicated ciliation with a number of different groups of cilia (Figs. 1 to 3). Most conspicuous is a system of slightly oblique transverse rows of 3 cells with large compound cilia repeated at a distance of 25 to $50 \mu \mathrm{m}$. The frontal end of the row is slightly closer to the base of the tentacle than the abfrontal end. Each of these compound cilia is about $8 \mu \mathrm{m}$ wide and $4 \mu \mathrm{m}$ thick, consisting of about 100 cilia arranged tightly in a honeycomb pattern (Fig. 3B). We refer to these compound cilia as Spikes I to III, where I is closest to the frontal side. About $1 \mu \mathrm{m}$ distal to the frontal end of each spike is a small compound cilium (referred to here as a cirrus), consisting of a circular to slightly oval

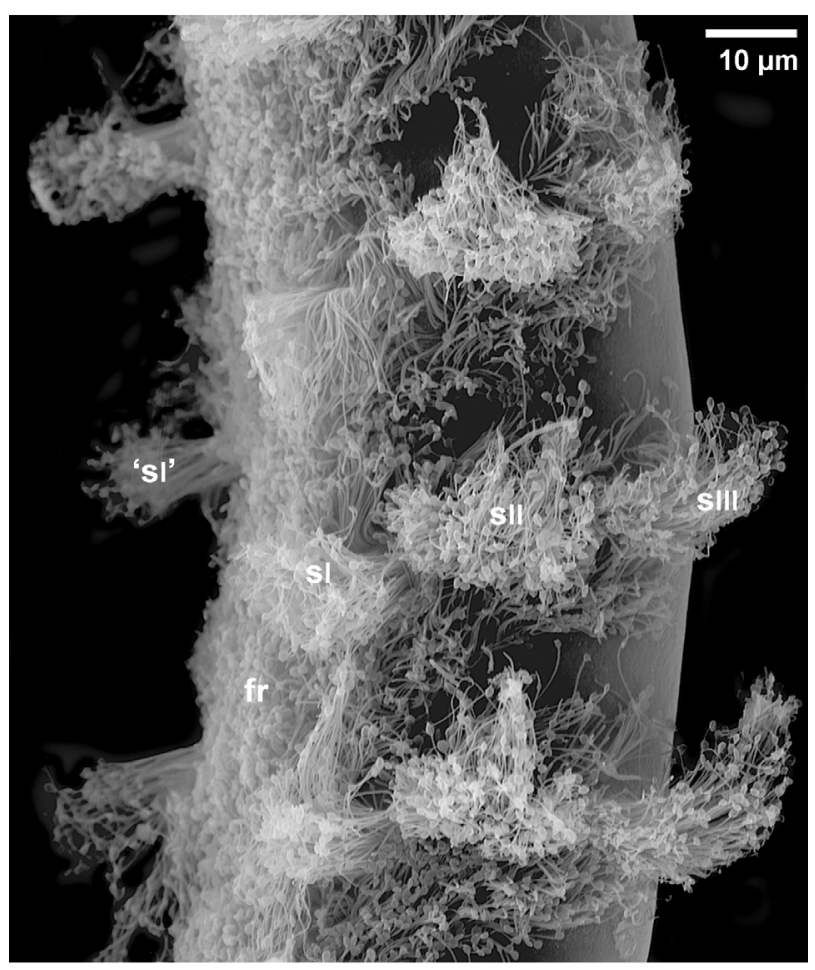

Fig. 1. Sabellaria alveolata. SEM. Slightly oblique, lateral view of a tentacle, showing 3 groups of large, compound cilia, called spikes (sI, sII, sIII); frontal cilia (fr) and the sI of the opposite side of the tentacle ('sI') are also visible. The distal end of tentacle is up in all scanning electron micrographs. The paddle cilia are artefacts 

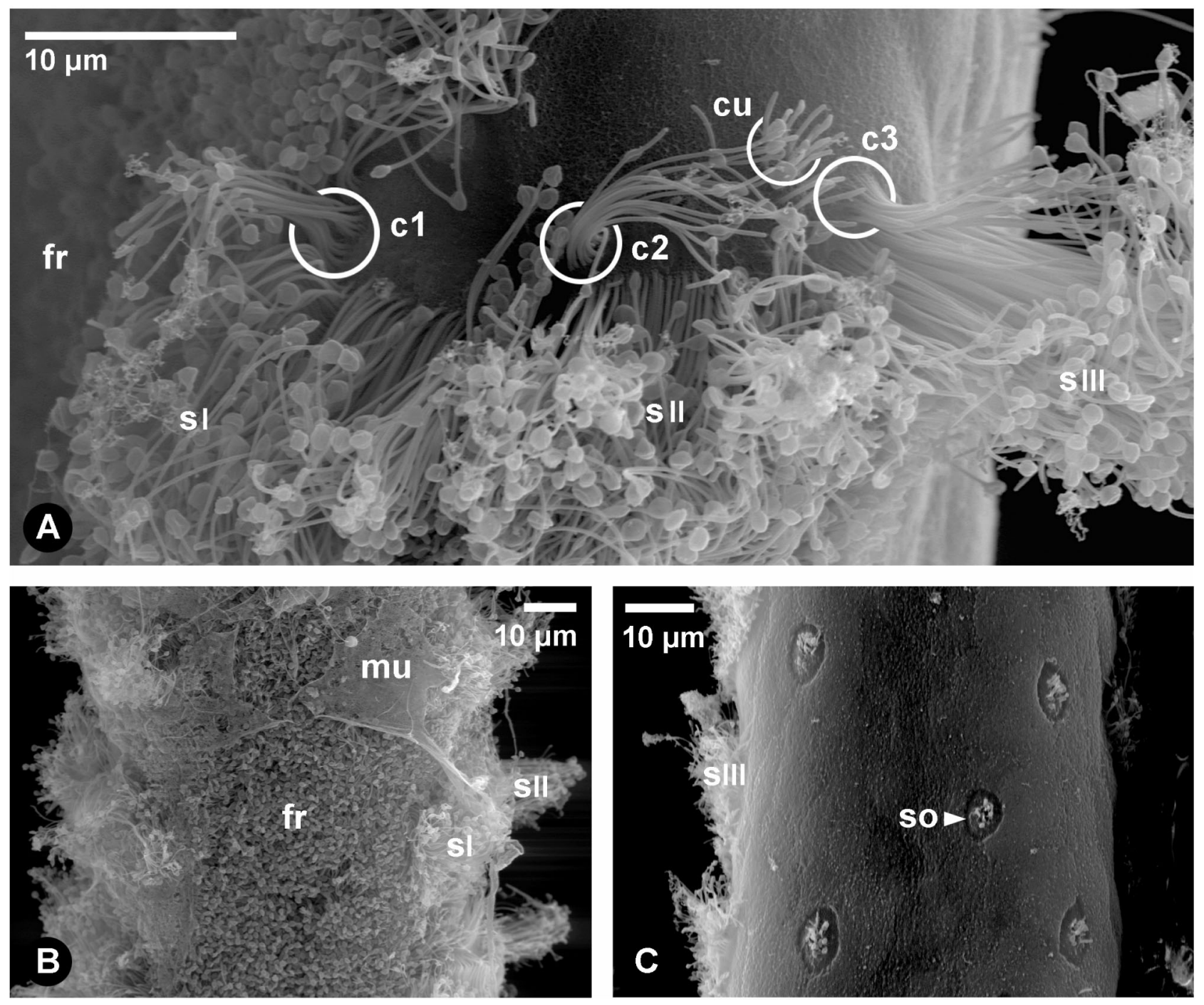

Fig. 2. Sabellaria alveolata. SEM. (A) Lateral view of a tentacle showing one of the slightly oblique transverse rows of ciliary spikes (sI, sII, sIII), the 3 cirri (c1, c2, c3) and a group of short cilia of unknown function (cu) situated near cirrus 3. (B) Frontal view of a tentacle showing the uniform frontal ciliation (fr), partly covered by a thin layer of mucus (mu). (C) Abfrontal view of a tentacle showing a number of small ciliated sensory organs (so)

group of tightly arranged, ca. $15 \mu \mathrm{m}$ long cilia (Fig. 2A). The shape of the fixed cirri indicates that they beat slightly obliquely towards the frontal side of the tentacle. A small group of more scattered cilia, each about $5 \mu \mathrm{m}$ long, is found near the frontal side of the most abfrontal spike (Fig. 2A).

The frontal side of the tentacle is flat or slightly concave and covered by a dense ciliation (Figs. 2B \& 3A). In some cases, a fine layer of mucus was observed to cover the frontal side of the tentacles more or less completely.

The abfrontal side of the tentacles is smooth with small, scattered sensory organs with a group of cilia (Figs. 2C \& 3C).

\section{Video observations}

Observation of living tentacles through the inverted microscope revealed that the compound cilia of each cell in the slightly oblique transverse rows of cells seen on SEM and TEM (Figs. 1 to 3) form a conical spike usually held in a stiff, upright position (Figs. 4 to 7 ; note: a video clip (\#1) related to Figs. 5 to 8 is available in MEPS Supplementary Material at www.int-res.com/ articles/suppl/m328p295_videos/). Spike I is short, ca. $15 \mu \mathrm{m}$ (Fig. 8), whereas Spikes II and III are longer, ca. 35 to $40 \mu \mathrm{m}$. Further, close to each spike, the cirrus of compound cilia (Fig. 2A) is actively beating with the active stroke obliquely towards the frontal side of the 

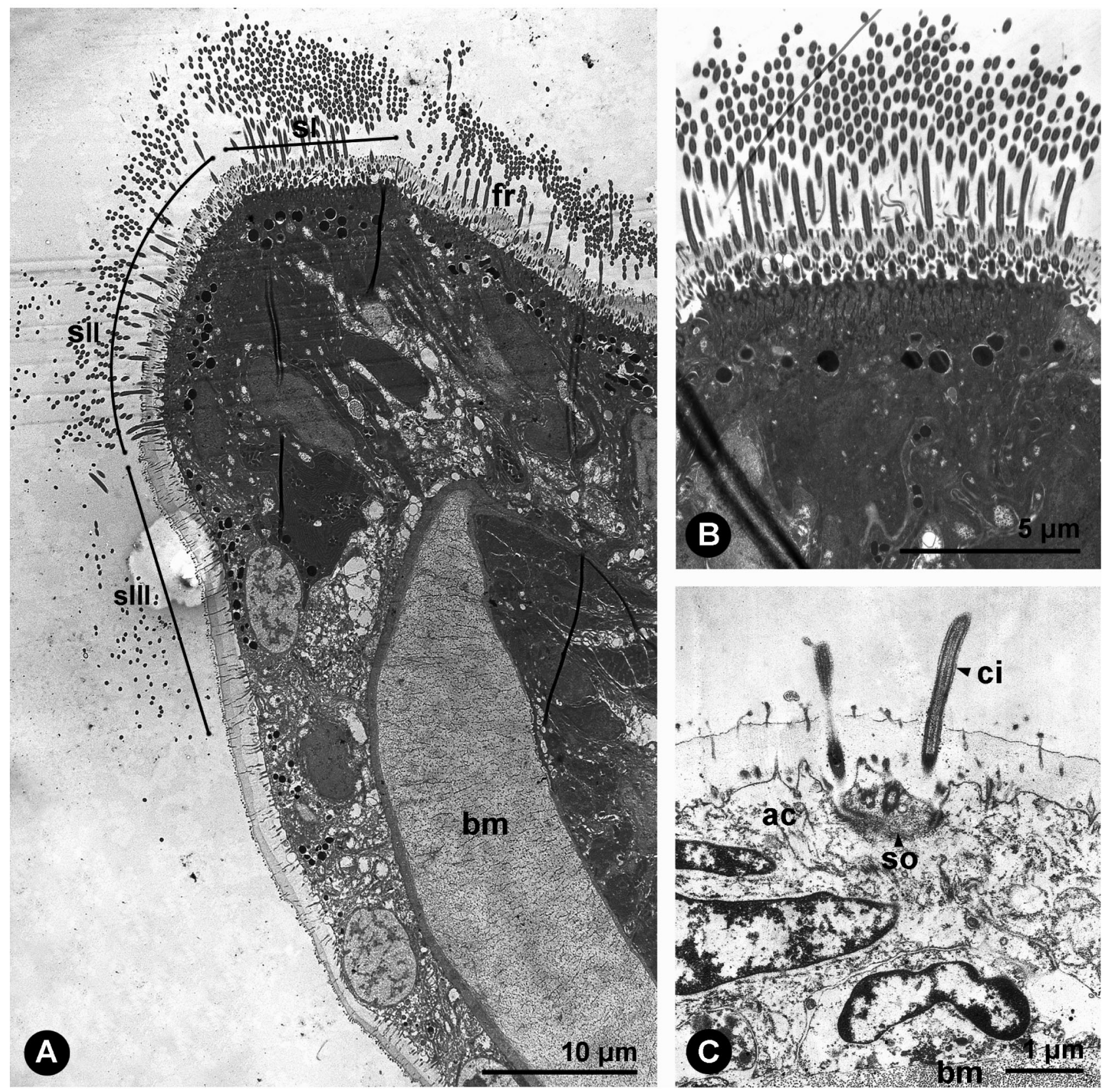

Fig. 3. Sabellaria alveolata. TEM of transverse sections of a tentacle. (A) Section of the 3 rows of ciliated lateral cells (sI, sII, sIII). The row is oblique, so the cell of the frontal spike (sI) is sectioned along the midline of the spike, sII along its distal side, and sIII is outside the section, with only parts of the cilia showing. (B) Detail of a frontal spike (sI) showing the tightly packed cilia. (C) Transverse section of a small abfrontal sensory organ showing the cilia. ac: abfrontal cell; bm: basal membrane; ci: cilium; so: sensory cell

filament, in a downward direction towards the base of the tentacle. The tentacles increase in width (measured on the frontal side) from about $40 \mu \mathrm{m}$ near the tip, to about $60 \mu \mathrm{m}$ in the middle, and up to $90 \mu \mathrm{m}$ near the base. The longitudinal distance between the regularly spaced spikes is ca. 45 to $55 \mu \mathrm{m}$. In filaments that are not fully extended, all the ciliary spikes are bent down parallel to the length of the tentacle with the tips towards the tentacle tip. However, it was frequently seen that single spikes could sporadically bend in the downward longitudinal direction of the tentacle, followed soon after by an active stroke to re-establish the stiff ciliary spike (Fig. 9) The ciliary spike may sometimes bend towards the tip of the tentacle and remain in this position for a shorter or longer period of time, or it may immediately begin the recovery movements to 

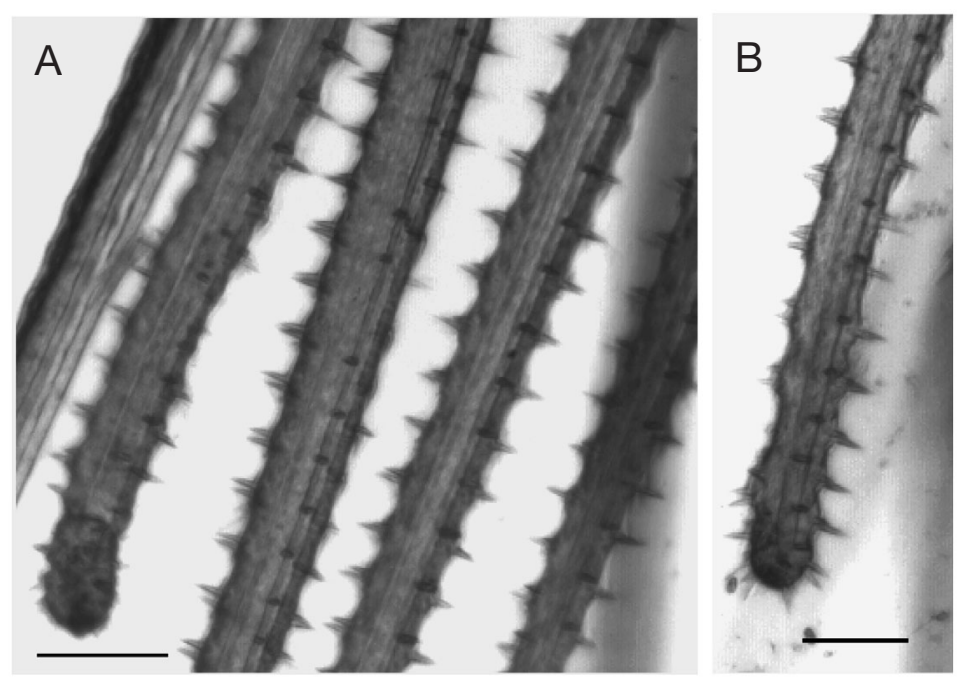

Fig. 4. Sabellaria alveolata. (A,B) Tentacles with rows of regularly spaced bundles of stiff cilia (spikes). Scale bars $=100 \mu \mathrm{m}$
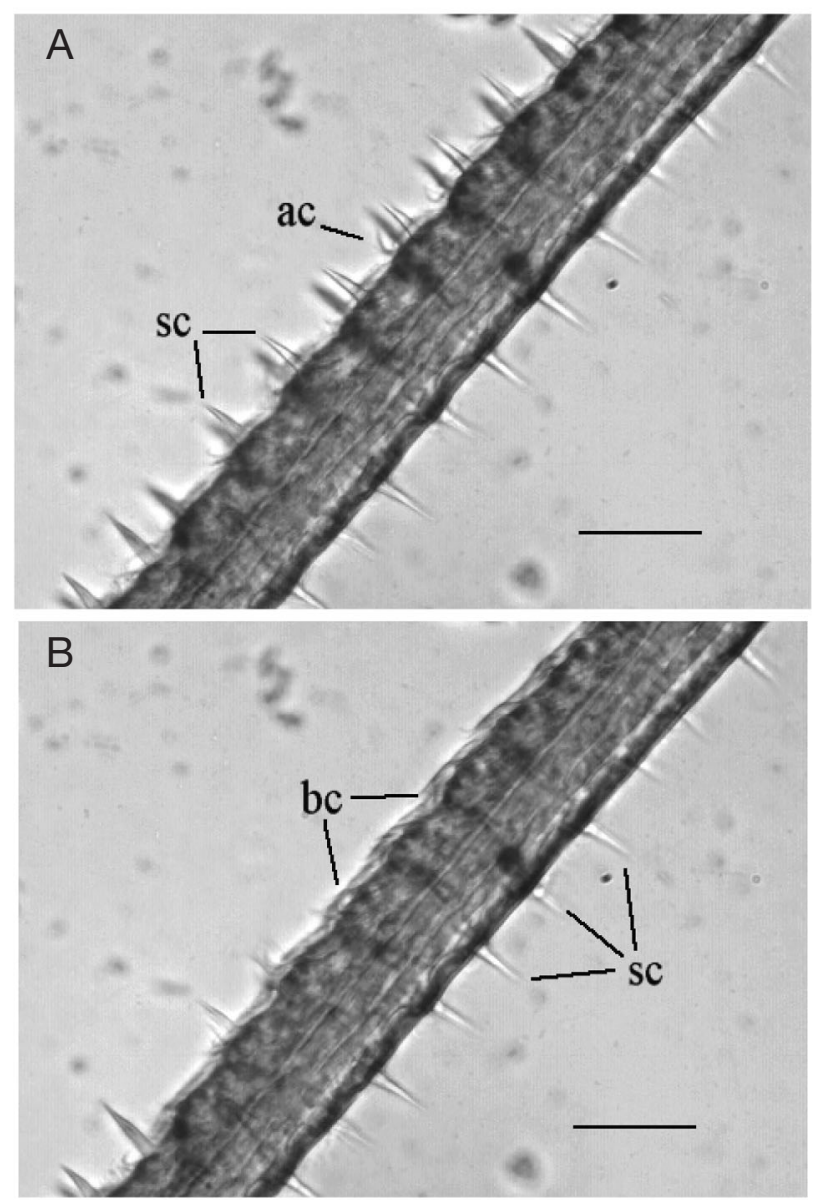

Fig. 5. Sabellaria alveolata. (A) Tentacle with rows of regularly spaced bundles of stiff cilia (sc: spikes) and small bundles of actively beating cilia (ac: cirri). (B) Rows of the usually stiff ciliary spikes (sc) bent down in the longitudinal direction of the tentacle (bc). Scale bars $=50 \mu \mathrm{m}$ end up in the stiff position. During the first part of the active stroke (at the end of which a ciliary spike is formed) the bundle of cilia moves through an angle of $90^{\circ}$ with a tip speed of about $4.5 \mathrm{~mm} \mathrm{~s}^{-1}$.

Tentacles that touched the bottom of the observation chamber of the inverted microscope were seen to pick up deposited particulate material which was transported on the frontal surface towards the mouth at a speed of 0.3 to $0.5 \mathrm{~mm} \mathrm{~s}^{-1}$ (Fig. 10). Suspended, $15 \mu \mathrm{m}$ diameter Tetraselmis sp. cells were not seen to be captured or transported on the tentacles, indicating that suspended algal cells are not a substantial part of the normal diet of Sabellaria alveolata.

Observations through the dissecting microscope of expanded 3 to $4 \mathrm{~mm}$ long tentacles of undisturbed individuals in a colony placed in a small glass observation aquarium also revealed regularly spaced rows of stiff ciliary spikes on each side of the tentacles. In stagnant water without suspended particles in the observation aquarium (re-circulating pump switched off) the expanded tentacles were generally rather stiff and motionless and no feeding currents were visible. However, when natural seston particles were added to the observation aquarium and flowing water conditions established (re-circulating pump switched on), suspended particles frequently encountered the tentacles to be retained, possibly by mucus adhesion, and subsequently transported towards the base of the tentacle and further towards the mouth. Particles were often captured, especially at the outer end of a tentacle, after a time lag of 0.5 to $2.5 \mathrm{~s}$, followed by a rapid bending of the tentacle tip. Frequently, this bending continued into a spi-

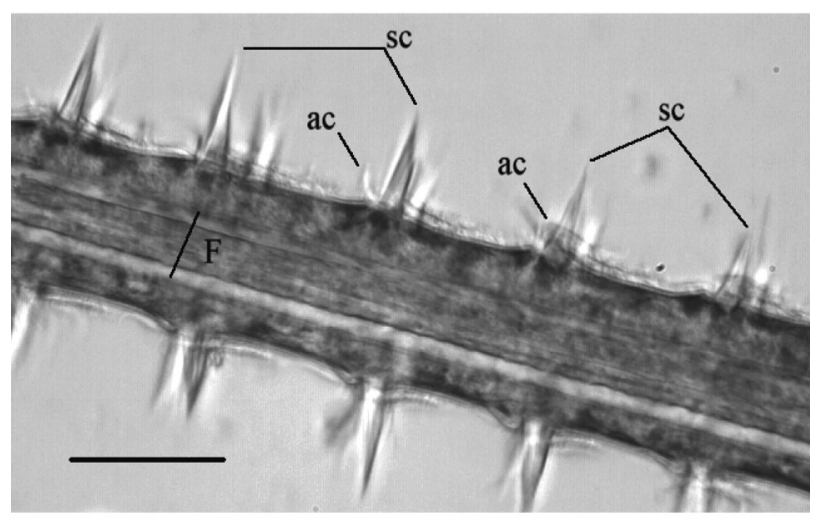

Fig. 6. Sabellaria alveolata. Tentacle with frontal ciliary groove $(\mathrm{F})$, rows of regularly spaced spikes (sc: bundles of stiff cilia), and small cirri (ac: bundles of actively beating cilia). Scale bars $=50 \mu \mathrm{m}$ 


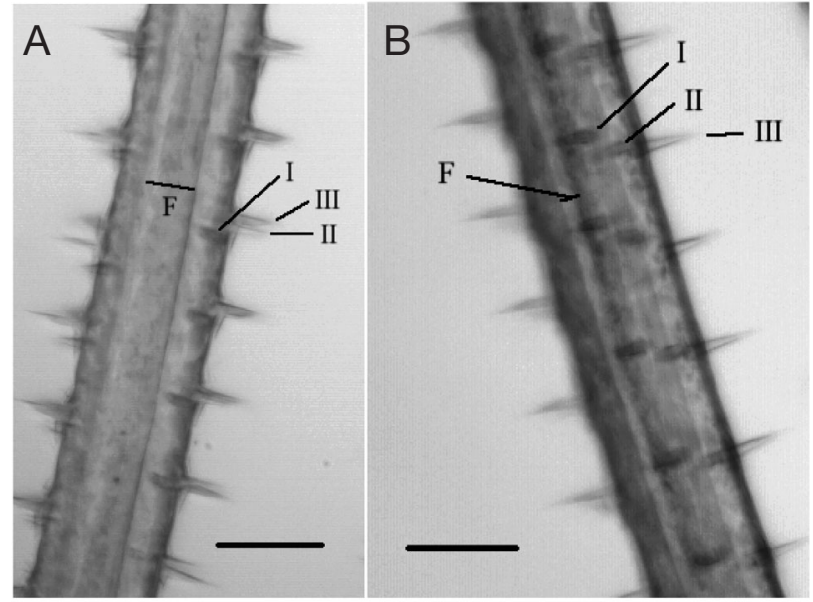

Fig. 7. Sabellaria alveolata. (A) Frontal view of tentacle. On each side of the frontal ciliary groove $(F)$ bundles of stiff cilia form a row of spikes (I), and obliquely below these on the lateral side of the tentacle another 2 bundles of stiff cilia (II and III) can be seen. (B) Laterofrontal view of tentacle. Scale bars $=50 \mu \mathrm{m}$

ral-like contraction of the whole tentacle, whereby captured particles stuck in mucus on the frontal side were rounded up in larger lumps that were subsequently transported further downwards on the frontal side towards the base of the tentacle (see Video clip \#2 at www.int-res.com/articles/suppl/m328p295_videos/). During the rapid tentacle bending/spiralling, captured particles did not lose contact with the surface of the tentacle; however, if they actually lost contact with the frontal ciliary groove, the particles appeared to stick together in a mucus string (Fig. 11). The initial bending speed of the tentacle tip was 8 to $10 \mathrm{~mm} \mathrm{~s}^{-1}$, and the velocity of captured particles on the frontal side was 0.1 to $0.5 \mathrm{~mm} \mathrm{~s}^{-1}$.

\section{DISCUSSION}

The present observations and interpretations of the structure and feeding mechanisms of the tentacles of Sabellaria alveolata disagree with those reported by Dubois et al. (2005). Our SEM and TEM preparations show that the lateral 'rows of long, grouped cilia' in fact consist of the highly organized compound cilia (which we call spikes), whereas the cirri (and the small group of short cilia) were not observed by Dubois et al. (2005). Instead of 1 longitudinal band on each side of the tentacles there are 3 longitudinal rows of distinct, aligned spikes. The structure reported here bears no resemblance to the downstream-collecting ciliary systems of other polychaetes, such as Sabella and Spirorbis, as described by Riisgaard et al. (2000).

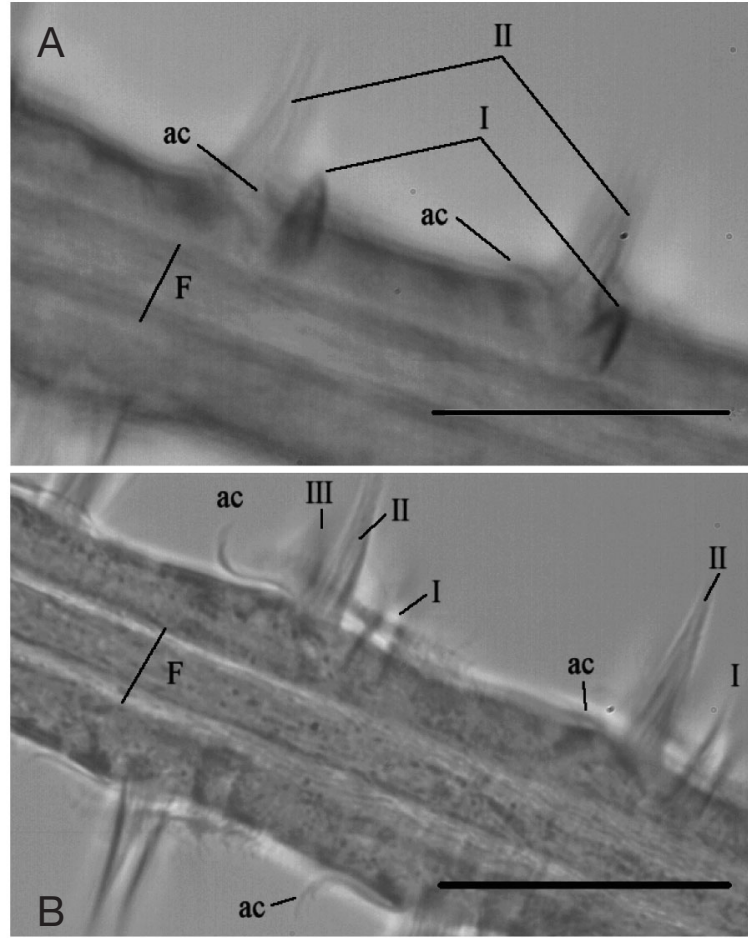

Fig. 8. Sabellaria alveolata. (A,B) Tentacle with frontal ciliary groove (F), short (I) and longer (II and III) bundles of stiff cilia (spikes), and actively beating cirri (ac). Scale bars $=50 \mu \mathrm{m}$

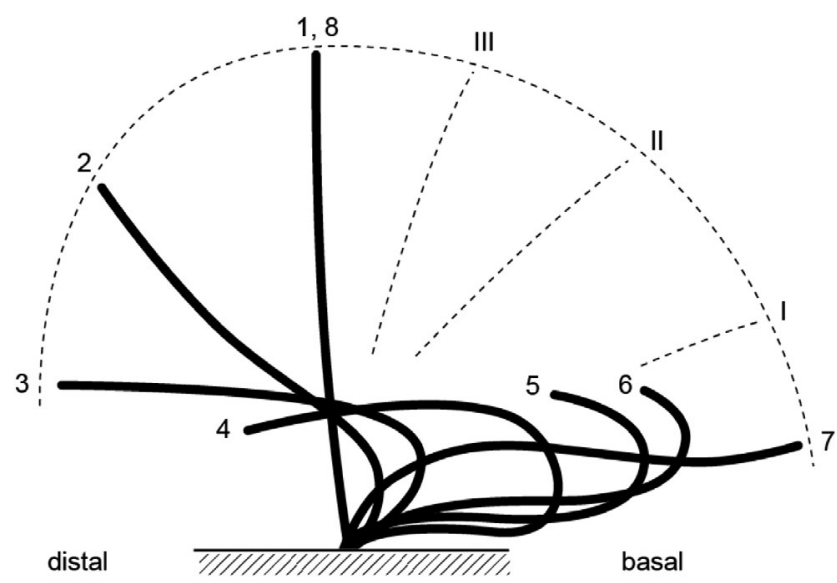

Fig. 9. Sabellaria alveolata. Movement of ca. $40 \mu \mathrm{m}$ long ciliary spike, consisting of a bundle of usually stiff cilia, traced from high-speed video-microscope pictures. It appears that the stiff spike condition (1) is established half-way through the normal active stroke phase (from 7 to 3 ) of a beating cilium. The stiff ciliary spike may bend distally (towards the tip of the tentacle) to position 3 and remain here for a shorter or longer period of time, or it may — as shown here - immediately begin the recovery movements to end up in the stiff position $(1,8)$. Time interval between different phases shown is $18 \mathrm{~ms}$ ( 5 frames), except for I, II and III, where the time interval is $3.6 \mathrm{~ms}$ ( 1 frame). During the active stroke from 7 to 8 , the ciliary tip velocity is ca. $4.5 \mathrm{~mm} \mathrm{~s}^{-1}$, while the tip speed during the active stroke from 1 to 3 is about $1.8 \mathrm{~mm} \mathrm{~s}^{-1}$ 


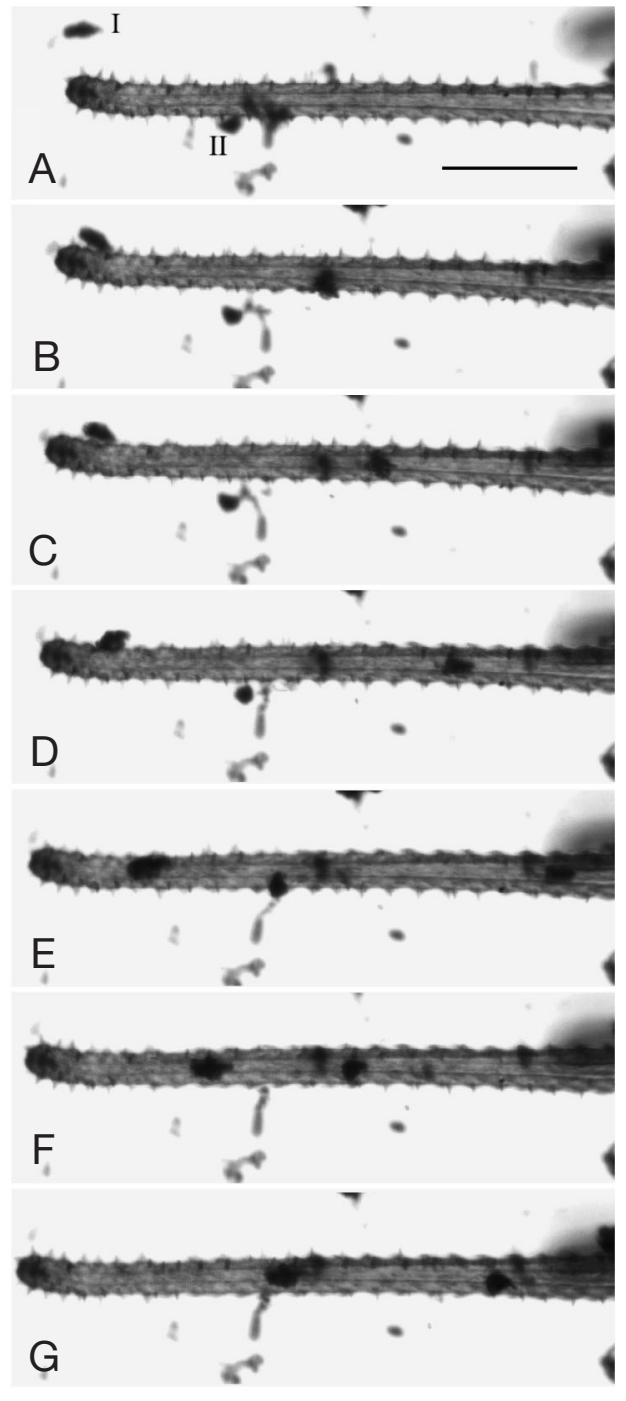

Fig. 10. Sabellaria alveolata. A tentacle picks up 2 particles (I, II) from the bottom of the inverted microscope observation chamber. (A-D) The tentacle tip moves first towards Particle I, which is transferred to the frontal side of the tentacle. $(\mathrm{D}, \mathrm{E})$ The tentacle is approaching Particle II, which is transferred to the frontal side, and subsequently transported downwards towards the base of the tentacle. The time interval between successive high-speed video frames is $0.36 \mathrm{~s}$. Scale bar (for A to G) $=2 \mathrm{~mm}$

Dubois et al. (2005) hypothesised that the lateral ciliary 'bands' of the Sabellaria alveolata tentacle should function by alternating as downstream and upstream particle collecting structures. We have observed that the spikes may bend, but that the stroke is parallel to the length of the tentacle, instead of towards the frontal ciliary band, as in a downstreamcollecting ciliary system functioning according to the catch-up principle, as described for Spirorbis, Ditrupa, Euchone, Loxosoma, and Symbion by Riisgaard et al.

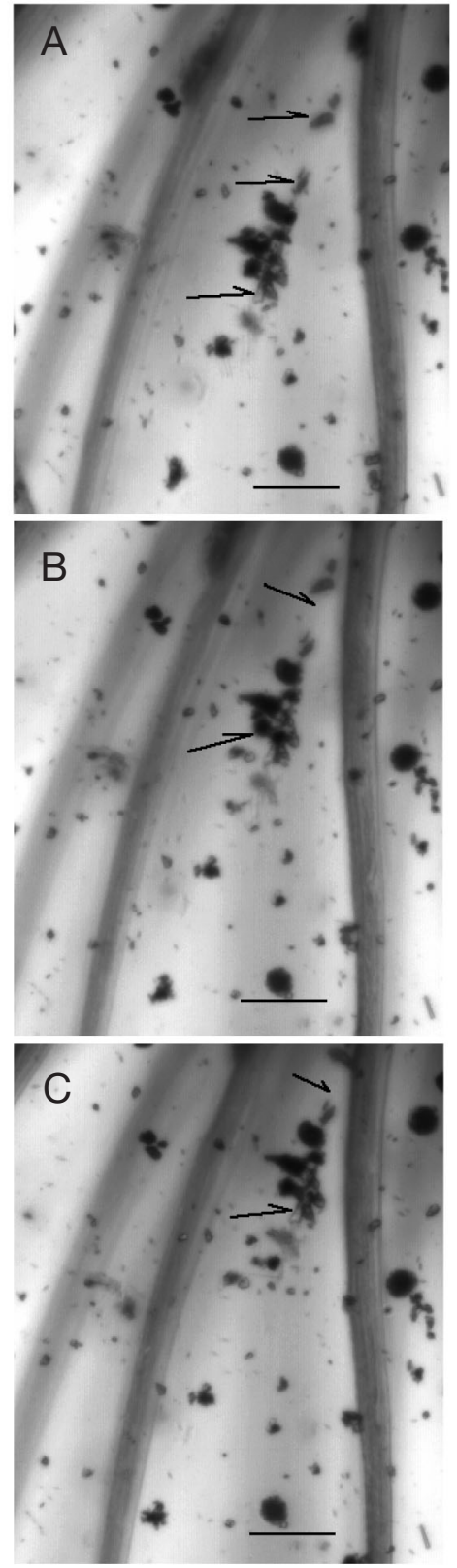

Fig. 11. Sabellaria alveolata. Particles in mucus string (arrows) distally released from the frontal ciliary groove of a tentacle, but the mucus string is nevertheless being pulled towards the base of the tentacle (top of picture) by a band of frontal cilia at a speed of ca. $0.4 \mathrm{~mm} \mathrm{~s}^{-1}$. Time interval between pictures $=0.36 \mathrm{~s}$. Scale bars $=0.2 \mathrm{~mm}$

$(2000,2002)$. In these forms, a strong feeding current is created by the compound cilia of the lateral band, which during their power stroke catch up with suspended particles which then suddenly become accelerated and move through an arc of about $180^{\circ}$ to be delivered on the frontal side of the tentacle. Our observations of $S$. alveolata show that there is no band of lateral compound cilia creating a water current, and we 
conclude that $S$. alveolata is not an active filter feeder. The obliquely beating cylindrical compound cilia, which we call cirri, may aid the transfer of encountered particles to the ciliary food groove on the frontal side of the filament. We characterize $S$. alveolata as a passive suspension feeder which captures suspended seston particles that encounter the tentacles when ambient water is passively flowing through the tentacle crown.

Both the structure and function of the Sabellaria alveolata tentacles are reminiscent of those of the palps of spionid polychaetes, such as Polydora commensalis (Dauer 1991), P. polybranchia (Qian \& Chia 1997), Dipolydora coeca, D. quadrilobata, P. cioliata, $P$. cornuta (Worsaae 2001), and Prionospio fallax (Worsaae 2003). Spionids are generally considered to be surface deposit feeders, using their 2 ciliated palps to select food particles from the sediment surface, but certain species can switch from deposit to suspension feeding by catching seston on the palps when the water current velocity and/or the concentration of suspended material becomes sufficiently high (Taghon et al. 1980, Shimeta \& Koehl 1997, Riisgård \& Kamermans 2001, Shimeta et al. 2004). The spionids collect particles on the palps, using mucus to retain and transport captured particles to the mouth along a median ciliated groove on the palp. It seems likely that $S$. alveolata has adapted to a similar way of life, being both a deposit and a passive suspension feeder; this suggestion is supported by the estimation below. Our interpretation is further supported by the nature of the stomach contents, which resemble unsorted detritus (Fig. 12).

The clearance rate per $\mathrm{cm}$ of ciliary band was determined by Riisgård et al. (2002, their Table 5) to be $0.4 \mathrm{ml} \mathrm{h}^{-1} \mathrm{~cm}^{-1}$ for Eucone papillosa and $0.6 \mathrm{ml} \mathrm{h}^{-1} \mathrm{~cm}^{-1}$ for Ditrupa arietina, while for Sabella pavonia $1.8 \mathrm{ml}$

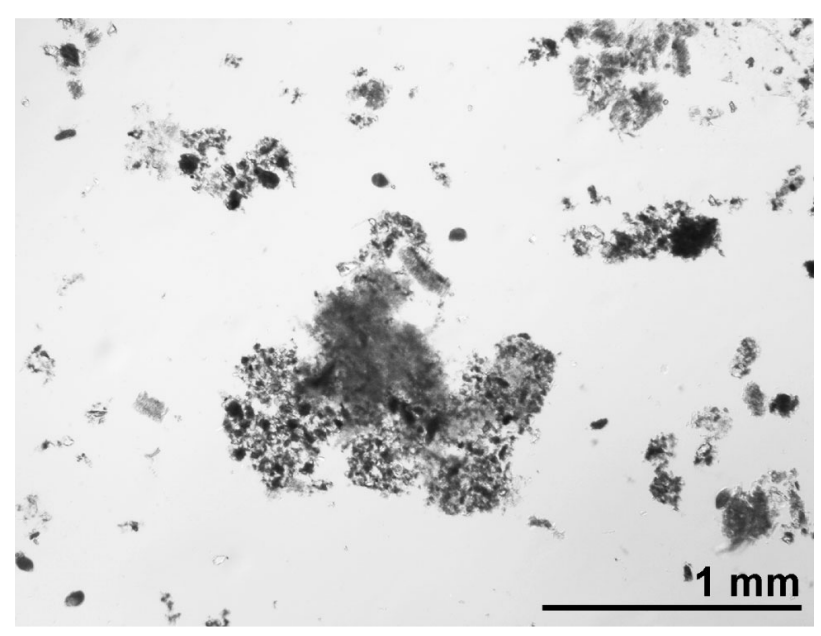

Fig. 12. Sabellaria alveolata. Stomach contents collected at low tide and fixed immediately. The contents consist of detritus and mineral particles $\mathrm{h}^{-1} \mathrm{~cm}^{-1}$ was calculated based on data in Riisgård \& Ivarsson (1990; see Riisgård et al. 2002, their Table 5). According to Dubois et al. (2005), the particle collecting system of an adult Sabellaria alveolata is represented by 250 tentacles extended $1 \mathrm{~cm}$ from the tube. With a similar suggested water pumping ciliary band on each side of the tentacles, the total length of such a band in $S$. alveolata would be $500 \mathrm{~cm}$, and with a comparable length-specific clearance rate of 0.4 to $1.8 \mathrm{ml}$ $\mathrm{h}^{-1} \mathrm{~cm}^{-1}$, the total individual clearance rate is estimated at 200 to $900 \mathrm{ml} \mathrm{h}^{-1}$ compared to only $0.75 \mathrm{ml} \mathrm{h}^{-1}$ reported by Dubois et al. (2003). The 267 to 1200 times lower clearance rate reported for $S$. alveloata indicates that it is not an active suspension feeder, as substantiated below.

The respiration rate $\left(R, \mathrm{ml} \mathrm{O}_{2} \mathrm{~h}^{-1}\right)$ of a mean $14 \mathrm{mg}$ dry wt Sabellaria alveolata can be roughly estimated from the equation $R=0.13 W(\mathrm{~g} \text { dry } \mathrm{wt})^{0.66}$, applying the data from Riisgård \& Ivarsson (1990) for Sabella pavonina, where $R=0.0078 \mathrm{ml} \mathrm{O}_{2} \mathrm{~h}^{-1}$, or by using $R=$ $0.141 W^{0.668}$, applying the data from Shumway et al. (1988) for the sabellid Myxicola infundibulum, where $R=0.0081 \mathrm{ml} \mathrm{O}_{2} \mathrm{~h}^{-1}$. By dividing the estimated $R$ of $0.008 \mathrm{ml} \mathrm{O}_{2} \mathrm{~h}^{-1}$ by the clearance rate of $0.00075 \mathrm{l} \mathrm{h}^{-1}$ measured for $S$. alveolata by Dubois et al. (2003) it can be deduced that an individual would filter ca. 0.091 water $\mathrm{ml}^{-1}$ oxygen consumed. This low value indicates that $S$. alveolata does not show the characteristics of a true filter feeder, which must be able to filter at least 101 water $\mathrm{ml}^{-1}$ oxygen consumed (Riisgård \& Larsen 2000).

Fabricia stellaris is a 2 to $3 \mathrm{~mm}$ long ciliary filterfeeding sabellid polychaete associated with the Sabellaria alveolata reefs (Dubois et al. 2002), as also observed in the present study (Fig. 13). The present

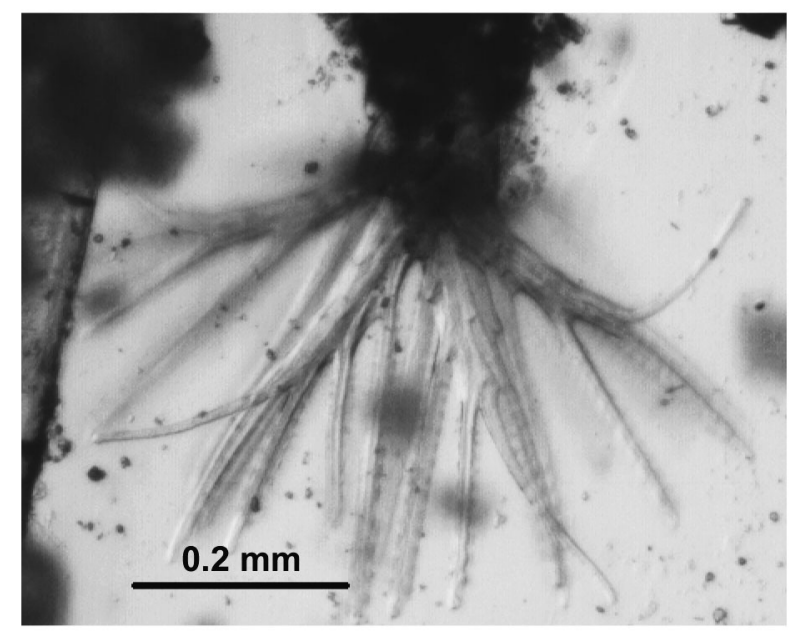

Fig. 13. Fabricia stellaris. This $1.8 \mathrm{~mm}$ long individual was associated with the Sabellaria alveolata colony observed in the present study 

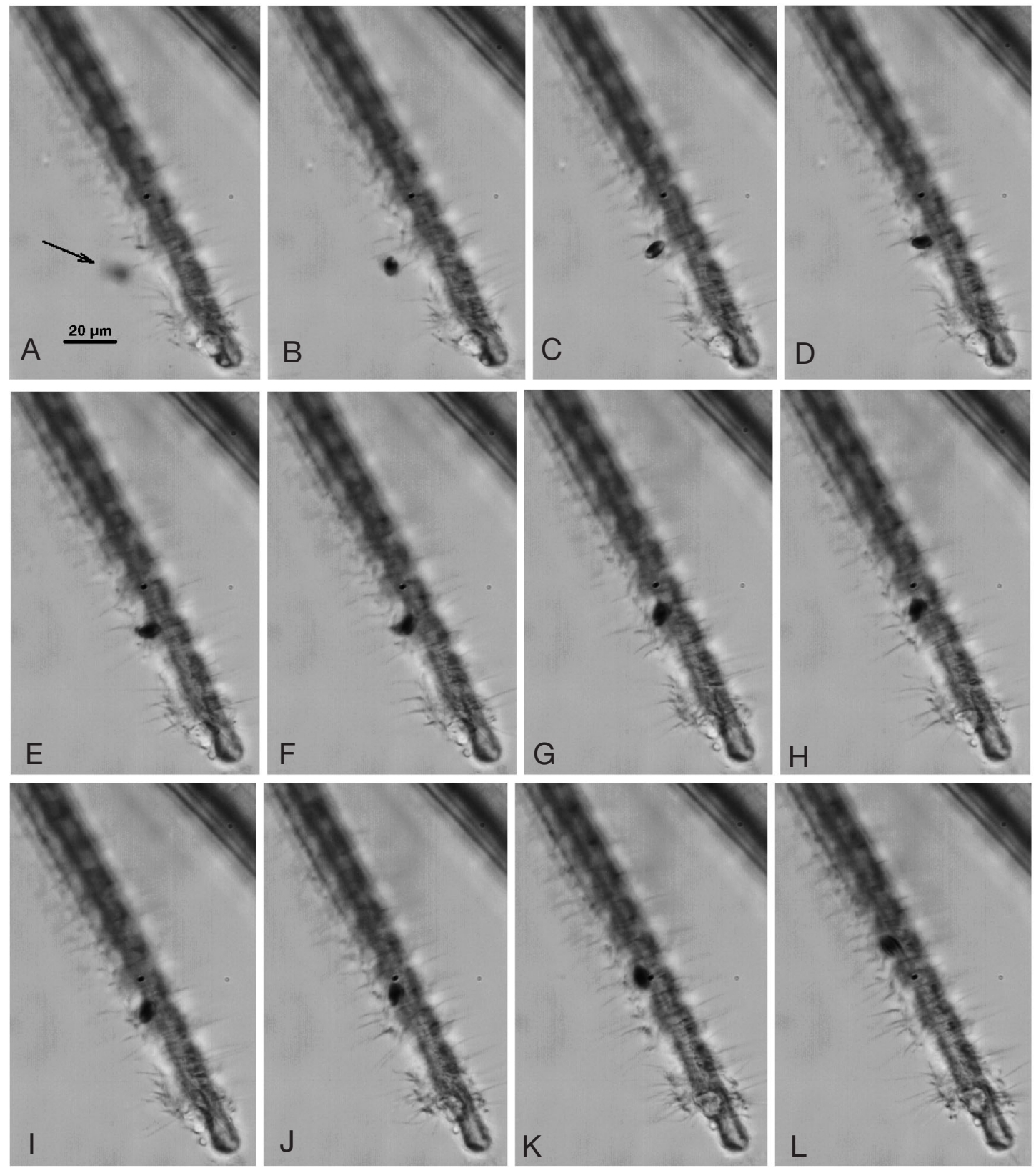

Fig. 14. Fabricia stellaris. (A-L) Particle capture of 6 m flagellate (Rhodomonas sp., arrow) by ciliary catch-up mechanism. Time interval between frames is $0.014 \mathrm{~s}$

high-speed video recordings (see Fig. 14 and also Video clip \#3 at www.int-res.com/articles/suppl/ m328p295_videos/) show that the feeding mechanism in F. stellaris is based on the catch-up principle (as described by Riisgård et al. 2000). The tentacle crown consists of 6 short radioles, each with 6 pairs of pinnules and a tapered tip. According to Fig. 13 the mean length of pinnules is about $0.25 \mathrm{~mm}$, and the total length of pinnules can thus be estimated to be $(6 \times 12 \times$ $0.25=18 \mathrm{~mm}$. The total length of the band of water pumping compound lateral cilia is therefore $(18 \times 2=)$ $36 \mathrm{~mm}$. If the volume of water cleared per cm ciliary band is $0.4 \mathrm{ml} \mathrm{h}^{-1}$ (as measured for the closely related filter-feeding polychaete Euchone papilosa [Riisgård et al. 2002], or $1.8 \mathrm{ml} \mathrm{h}^{-1}$ for Sabella pavomina [Riisgård \& Ivarsson 1990, Riisgård et al. 2002, their Table 5]), the clearance rate of the F. stellaris is estimated to be $(3.6 \times 0.4=) 1.4$ and $3.2 \mathrm{ml} \mathrm{h}^{-1}$, respectively. According to Dubois et al. (2002, their Table 1) the density of $F$. stellaris is ca. $16 \%$ of the $S$. alveolata 
population density reported from the $S$. alveolata reefs in the bay of Mont Saint-Michel, France. In clearance rate experiments conducted by Dubois et al. (2003), the flow-through chamber techniques and intact blocks of $S$. alveolata reef were used. The reef blocks may, however, have been 'contaminated' with F. stellaris. The mean clearance rate of an individual $S$. alveolata was measured by Dubois et al. (2003) to be $0.75 \mathrm{ml} \mathrm{h}^{-1}$, but from the above calculations this value may be explained solely by the filter-feeding activity of the associated F. stellaris if the density of this worm were about 2 to 4 times lower than that of $S$. alveolata.

Dubois et al. (2005) hypothesised that Sabellaria alveolata 'displays some of the same feeding mechanisms as those of lophophorids (phoronids, brachiopods and bryozoans)'. They further suggested that 'tentacle flicking movements are probably responsible for the alteration of currents within the tentacle-crown and help in particle capture' so that 'the characteristic features of particle capture in S. alveolata have strong similarities with those observed and described in lophophorids'. These statements are not supported by our observations. Ciliary upstream particle capture has in recent years been thoroughly described in bryozoans (Riisgård \& Manríquez 1997, Nielsen \& Riisgård 1998, Larsen \& Riisgård 2002) as well as in the phoronid Phoronis muelleri (Riisgård 2002). The upstream method, also referred to as 'ciliary sieving', is rather similar in bryozoans and phoronids: a row of stiff, sensory laterofrontal cilia is placed upstream of the water pumping lateral cilia band. Particles in the currents are retained by the stiff laterofrontal ciliary filter and either transported downwards on the tentacles by means of frontal cilia on the frontal side of the tentacles, or the particles are transferred to the core current by means of inward tentacle flicks triggered by the arrested particles. The present observations on both feeding structures and their function in S. alveolata do not resemble the above description of upstream collection, and we think it is misleading to compare the function of tentacle bending/spiralling that we observed in $S$. alveolata to the function of tentacle flicks in ciliary filter-feeding bryozoans and phoronids.

\section{CONCLUSIONS}

The present study shows that the tentacles of intact and undisturbed Sabellaria alveolata have a large number of ciliary spikes (compound cilia), which are usually kept stiff, but which may beat nearly parallel to the length of the tentacle, each flanked by an actively beating cirrus. No structured flow of water is created and only minor local currents are seen. Clearly, S. alveolata does not possess a proper ciliary pump as found in true ciliary suspension-feeding invertebrates. This indicates that $S$. alveolata's tentacle crown is designed for passive suspension feeding and thus dependent on ambient currents to bring suspended food particles into contact with the tentacles. The fluid mechanical significance of the ciliary spikes remains unknown. However, the present observations suggest that mucus is involved in both the capture and transport of food particles in S. alveolata, possibly in a similar way as in spionid polychaetes (Shimeta et al. 2004). The 3 types of mucocytes identified in $S$. alveolata by Dubois et al. (2005), who also found secretory pores scattered among the frontal cilia, support this statement.

Acknowledgements. H.U.R. and C.N. were funded by grants from the Danish Natural Science Research Council (Nos. 2103-0481 and 21-04-0022, respectively). We acknowledge Dr. Poul S. Larsen for his comments on the manuscript, Mr. Gert Brovad and Birgitte Rubæk (Zoological Museum) for help with the illustrations, Dr. Åse Jespersen (Biological Institute) for help with the TEM work, and Ms. Céline Houbin (Station Biologique Roscoff) for collecting animals for investigation of stomach contents.

\section{LITERATURE CITED}

Dauer D (1991) Functional morphology and feeding behavior of Polydora commensalis (Polychaeta: Spionidae). Ophelia (Suppl) 5:607-614

Dubois S, Retière C, Olivier F (2002) Biodiversity associated with Sabellaria alveolata (Polychaeta: Sabellariidae) reefs: effects of human disturbances. J Mar Biol Assoc UK 82: $817-826$

Dubois S, Barillé L, Retière C (2003) Efficiency of particle retention and clearance rate in the polychaete Sabellaria alveolata L. CR Biol 326:413-421

Dubois S, Barillé L, Cognie B, Beninger PG (2005) Particle capture and processing mechanisms in Sabellaria alveolata (Polychaeta: Sabellariidae). Mar Ecol Prog Ser 301: 159-171

Gilmour THJ (1978) Ciliation and function of the food-collecting and waste-rejecting organs of lophophorates. Can J Zool 56:2142-2155

Larsen PS, Riisgård HU (2002) On ciliary sieving and pumping in bryozoans. J Sea Res 48:181-195

Nielsen C (1987) Structure and function of metazoan ciliary bands and their phylogenetic significance. Acta Zool 68:205-262

Nielsen C, Riisgård HU (1998) Tentacle structure and filterfeeding in Crisia eburnea and other cyclostomatous bryozoans, with a review of upstream-collecting mechanisms. Mar Ecol Prog Ser 168:163-186

Qian PY, Chia FS (1997) Structure of feeding palps and feeding behavior of the spionid polychaete Polydora polybranchia. Bull Mar Sci 60:502-511

Riisgård HU (2002) The methods of ciliary filter feeding in the adult Phoronis muelleri and its free swimming actinotrocha larva. Mar Biol 141:75-87

Riisgård HU, Ivarsson NM (1990) The crown-filament-pump of the suspension-feeding polychaete Sabella penicillus: filtration, effects of temperature, energy cost, and modelling. Mar Ecol Prog Ser 62:249-257 
Riisgård HU, Kamermans P (2001) Switching between deposit and suspension feeding in coastal zoobenthos. In: Reise K (ed) Ecological comparisons of sedimentary shores. Ecological studies. Springer-Verlag Berlin, p 73-101

Riisgård HU, Larsen PS (2000) Comparative ecophysiology of active zoobenthic filter-feeding, essence of current knowledge. J Sea Res 44:169-193

Riisgård HU, Manríquez P (1997) Filter-feeding in fifteen marine ectoprocts (Bryozoa): particle capture and water pumping. Mar Ecol Prog Ser 154:223-239

Riisgård HU, Nielsen C, Larsen PS (2000) Downstream collecting in ciliary suspension feeders: the catch-up principle. Mar Ecol Prog Ser 207:33-51

Riisgård HU, Grémare A, Amouroux AJM, Vétion G, Charles F, Rosenberg R, Nielsen C (2002) A comparative study of water processing in two ciliary filter-feeding polychaetes (Ditrupa arietina and Euchone papillosa) from two different habitats. Mar Ecol Prog Ser 229: $113-126$

Editorial responsibility: Otto Kinne (Editor-in-Chief), Oldendorf/Luhe, Germany
Shimeta J, Koehl MAR (1997) Mechanisms of particle selection by tentaculate suspension feeders during encounter, retention, and handling. J Exp Mar Biol Ecol 209:47-73

Shimeta J, Witucki PF, Hippe KR (2004) Influences of nutritional state and temperature on suspension-feeding rates and mechanisms in the spionid polychaete Polydora cornuta. Mar Ecol Prog Ser 280:173-180

Shumway SE, Bogdanowicz C, Dean D (1988) Oxygen consumption and feeding rates of the sabellid polychaete Myxicola infundibulum (Renier). Comp Biochem Physiol 90A:425-428

Taghon GL, Nowell, ARM, Jumars PA (1980) Induction of suspension feeding in spionid polychaetes by high particulate fluxes. Science 210:562-564

Worsaae K (2001) The systematic significance of palp morphology in the Polydora complex (Polychaeta: Spionidae). Zool Anz 240:47-59

Worsaae K (2003) Palp morphology in two species of Prionospio (Polychaeta: Spionidae). Hydrobiologia 496:259-267

Submitted: July 7, 2006; Accepted: November 13, 2006

Proofs received from author(s): November 27, 2006 